\title{
Editorial
}

\section{Early Buried Bumper Syndrome - To Leave or Not to Leave}

\author{
Diogo Libânio ${ }^{a, b}$ Pedro Pimentel-Nunes ${ }^{a, b}$

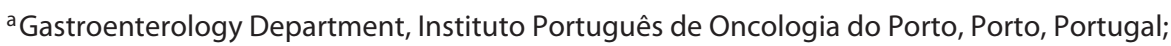 \\ ${ }^{b}$ MEDCIDES - Departamento Medicina da Comunidade, Informação e Decisão em Saúde, Porto, Portugal
}

\section{Keywords}

Percutaneous endoscopic gastrostomy · Endoscopy ·

Stomach · Adverse events · Buried bumper syndrome

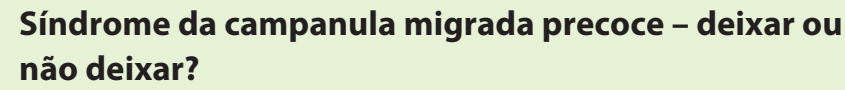

\section{Palavras Chave}

Gastrostomia endoscópica percutânea - Endoscopia · Estômago · Eventos adversos · Síndroma da campânula migrada

Buried bumper syndrome (BBS) is an uncommon adverse event of percutaneous endoscopic gastrostomy (PEG), yet it should be thoroughly managed because its consequences can be serious and life-threatening. BBS is typically a late adverse event of PEG and its management is more straightforward in these cases since a mature gastrocutaneous fistula poses fewer risks when it is necessary to remove the buried bumper. Early presentations were rarely reported and so the management in these cases remains largely on the physician's personal experience and clinical sense. The decision of what to do in these rare

\section{KARGER}

E-Mail karger@karger.com www.karger.com/pjg
(C) 2018 Sociedade Portuguesa de Gastrenterologia Published by S. Karger AG, Basel

Karger

Upen access

This article is licensed under the Creative Commons AttributionNonCommercial-NoDerivatives 4.0 International License (CC BYNC-ND) (http://www.karger.com/Services/OpenAccessLicense). Usage and distribution for commercial purposes as well as any distribution of modified material requires written permission. cases should take into account not only the best way to avoid serious complications, but also the issue of how nutrition will be delivered if the gastrostomy is removed. In this issue of GE - Portuguese Journal of Gastroenterology, two opposite management approaches for early BBS are presented by Azevedo et al. [1] and Pinho et al. [2].

In the first case, a patient with Alzheimer disease presented with BBS 3 days after PEG placement [1]. As the bumper was totally embedded in the gastric wall and the internal orifice of the gastrocutaneous fistula was not identified, the authors decided to remove the bumper and tube as no resistance was noted. The patient was admitted for surveillance and antibiotherapy, and no adverse events were noted including on abdominal imaging. Nutrition was secured via oral route in this case as the patient maintained some oral intake.

In the second case, a patient under adjuvant chemoradiotherapy for oropharyngeal cancer presented with BBS 2 weeks after the procedure, with a newly formed cavity in the abdominal wall [2]. As the patient exhibited aphagia and endoscopic access was difficult (due to anatomic deformation and patient will), a conservative approach was attempted in order to leave the gastrostomy in place. A guidewire was passed to the stomach through the gastrostomy tube without resistance and the bumper was repositioned in the stomach under gentle traction. Peri- 
stomal infection was successfully treated with directed antibiotherapy, and the patient was able to reinitiate tube feeding 7 days after admission and was able to continue chemoradiation therapy after discharge.

The two presented cases represent two different successful alternatives for the same adverse event of PEG placement, both with advantages and drawbacks. Removing the bumper in an early BBS decreases the risk of abdominal wall infection, although this strategy should only be attempted if no resistance is found due to the risk of peritonitis and fistula formation in an immature tract. This approach also has the disadvantage of removing the ideal route of feeding. The leave strategy can also be attempted if the bumper can be safely repositioned into the stomach using a guidewire and minimal resistance is felt, but it is also associated with a higher risk of infection and sepsis if the bumper maintains in a misplaced position, and endoscopic confirmation of intragastric position should be performed whenever possible. This approach also has the advantage of maintaining the tube feeding in place in order to guarantee enteral nutrition.

Different approaches reported in the literature so far that can also be an option in early BBS include reposition of the buried bumper in the gastric lumen or extraction and subsequent placement of a new tube through the same or adjacent tract with the following strategies:

- passing a guidewire to the stomach lumen under endoscopic control and repositioning, with a bougie or a hydrostatic balloon dilator to provide stiffness to the tube $[3,4]$;

- repositioning of an incomplete buried bumper with a grasper under endoscopic guidance [3];
- performing radial incisions over the bumper with a wire-guided papillotome after guidewire cannulation of the stomach [3];

- performing radial star-like incisions of the gastric inner wall with a needle-knife to expose the bumper in cases in which it is completely embedded in the gastric wall [5];

- under standard endoscopic control, introduction of a thin gastroscope through the PEG tube to guide repositioning using rotational movements and direct view (or a conventional gastroscope if the tube diameter allows its passage) [6];

- external removal of the buried bumper after radial incisions in the abdominal wall [7];

- repositioning of the bumper with stiff guidewire and/ or bougie under fluoroscopic guidance [8].

With the wide array of endoscopic and radiological strategies to successfully manage BBS, laparotomy and surgical removal should only be considered in case of peritonitis, sepsis or complex fistulous tracts [9].

This adverse event is fortunately rare and prospective studies and trials are not expected to answer the question of which is the best management strategy; however, case reports such as those presented in this issue may help us answering the question: to leave or not to leave.

\section{Disclosure Statement}

The authors have no conflicts of interest to declare.

\section{References}

1 Azevedo R, Caldeira A, Banhudo A: Early presentation of buried bumper syndrome. GE Port J Gastroenterol 2017. DOI: 10.1159/000478943.

-2 Pinho J, Libânio D, Pimentel-Nunes P, DinisRibeiro M: The challenging acute buried bumper syndrome: a case report. GE Port J Gastroenterol 2017. DOI: 10.1159/000485104.

-3 Mueller-Gerbes D, Hartmann B, Lima JP, de Lemos Bonotto M, Merbach C, Dormann A, Jakobs R: Comparison of removal techniques in the management of buried bumper syndrome: a retrospective cohort study of $82 \mathrm{pa}-$ tients. Endosc Int Open 2017;5:E603-E607.
4 Christiaens P, Bossuyt P, Cuyle PJ, Moons V, Van Olmen A: Buried bumper syndrome: single-step endoscopic management and replacement. Gastrointest Endosc 2014;80:336.

5 Kurek K, Baniukiewicz A, Swidnicka-Siergiejko A: Buried bumper syndrome: a rare complication of percutaneous endoscopic gastrostomy. Wideochir Inne Tech Maloinwazyjne 2015;10:504-507.

6 Taher MM, Kosai NR, Gendeh HS: Creative treatment of early buried bumper syndrome. Ann R Coll Surg Engl 2014;96:621-622.
7 Benatta MA: The buried bumper syndrome: external bumper extraction after radial mini incisions and replacement through an adjacent tract. Case Rep Med 2016;2016:5379291.

-8 Crowley JJ, Vora D, Becker CJ, Harris LS: Radiologic removal of buried gastrostomy bumpers in pediatric patients. AJR Am J Roentgenol 2001;176:766-768.

-9 Afifi I, Zarour A, Al-Hassani A, Peralta R, ElMenyar A, Al-Thani H: The challenging buried bumper syndrome after percutaneous endoscopic gastrostomy. Case Rep Gastroenterol 2016;10:224-232. 